\title{
Saamelaisperinteestä, palauttamisen hengessä
}

\author{
Dálvadasa šurra, šárra ja hurra -seminaari Karigasniemellä 30.8.2018
}

\author{
Pasi Enges ja Tiina Mahlamäki
}

\begin{abstract}
Šurra on ääni, joka kuuluu kauempana olevan ihmisjoukon puheesta, hurinaa, jorinaa, surinaa tai turinaa. Šárra on rahinaa, joka lähtee duodjáreiden hioessa hiekkapaperilla puisia käsitöitään ja hurra on hyräilyä, joka lähtee ihmisestä kun hän työmielellä tekee käsitöitä.
\end{abstract}

Lainaus on Utsjoen Karigasniemellä, kylätalo Sáivussa elokuussa 2018 avatun valokuvanäyttelyn esitteestä. Esille asetetut kuvat ovat peräisin vuonna 1967 käynnistetyn Saamelaisen folkloren tutkimusprojektin aineistosta, joka on taltioitu Turun yliopiston historian, kulttuurin ja taiteiden tutkimuksen arkistoon. Näyttelyyn liittyen pidettiin kylätalossa 30.8.2018 seminaari, jossa muisteltiin ja tehtiin tunnetuksi yli viisikymmentä vuotta sitten aloitettua tutkimusprojektia ja sen aineistoja. Pääkohteensa, ylätenolaisen Dálvadas-kylän mukaan, mutta suomenkielisessä asussa Talvadas-projektina tunnetun tutkimushankkeen aineistoa on pidetty arkistossa sen eräänlaisena kruununjalokivenä, ja sen pohjalta on tehty suuri määrä tieteellisiä julkaisuja ja opinnäytteitä. Projektin ensisijainen tavoite olikin aineiston muodostaminen tieteellisen tutkimuksen käyttöön. Sen lisäksi nopeasti muuttuvaksi nähty saamelaiskulttuuri haluttiin dokumentoida ja "pelastaa häviämiseltä", ja varmin turvapaikka vanhalle perinteelle löytyi arkiston seinien sisältä.

Lapissa 1960-luvulla vauhtiin päässyt ja nopea modernisoituminen on muuttanut suuresti paikallista elämäntapaa, mutta ennakoidusta kulttuurin kuihtumisesta ei sentään voida puhua. Yllä olevassa lainauksessa kuvatut äänet ovat lähes täysin vaienneet Dálvadaksen kylässä, ja tutkimusprojektin alkuperäiset haastateltavat ovat paria poikkeusta lukuun ottamatta jo edesmenneitä. Heidän ääniään on kuitenkin taltioitu arkistoon - siksi 1960-luvun arkinen äänimaisema sopii erinomaisesti valokuvanäyttelyn ja seminaarin otsikoksi. Nuorempien, omista juuristaan tietoisten ja kiinnostuneiden sukupolvien myötä on herännyt uudenlainen, ajoittain kriittinenkin kiinnostus arkistoitua saamelaisperinnettä kohtaan.

Palauttaminen ja repatriaatio ovat käsitteitä, joilla viime vuosikymmeninä on kuvattu alkuperäiskansoilta peräisin olevien materiaalien omistusoikeuden tunnustamista ja niiden palauttamista alueille, yhteisöille tai henkilöille, joilla tuon oikeuden katsotaan olevan (Skrydstrup 2009). Saamelaiskulttuurin osalta se on toistaiseksi merkinnyt lähinnä aineellista kulttuuria, kuten museoesineitä (esim. Harlin 2008; Aromaa 2017). Esineet ovatkin tavallaan selkeitä (joskaan eivät ongelmattomia) palautettavia: ne on fyysisesti viety pois alkuperäisiltä 
omistajiltaan ja ne voidaan - ainakin periaatteessa - myös palauttaa alkuperäisinä. Kertomuksia, muistitietoa ja muuta henkistä perinnettä ei samalla tavoin voi viedä pois, mutta siitä voi tehdä dokumentteja, jotka puolestaan on tavallisesti sijoitettu etäälle alkuperäisestä kontekstistaan. Kun paikallinen, arkinen suullinen perinne alkaa uusien sukupolvien silmissä näyttää arvokkaalta kulttuuriperinnöltä ja tärkeältä osalta oman perheen ja suvun historiaa, asettuvat myös arkistoidut aineistot uuteen valoon. Kriittisimmissä puheenvuoroissa on kokonaan kyseenalaistettu etelästä tulleiden tutkijoiden oikeus saamelaisten aineettomaan perinteeseen. Kenellä on oikeus äänitteille taltioituihin kertomuksiin, joikuihin tai paikallishistoriaa ja elinkeinoja koskevaan tietouteen? Voimassa olevan lainsäädännön suhteen asia on kohtalaisen yksinkertainen: omistusoikeus aineistoon on arkistolla ja tekijänoikeus haastatteluihin ne tehneillä tutkijoilla. Mutta entä äänitteiden sisällöt ja niiden tuottamiseen liittyvät tekijänoikeudelliset ja eettiset kysymykset?

\section{Tapahtuman taustaa}

Talvadas-projekti edusti aikanaan täysin uudenlaista kenttätutkimusta. Yhden tenonsaamelaisen kylän suullinen perinne ja sen välittyminen yhteisössä pyrittiin dokumentoimaan niin täydellisesti kuin mahdollista, ja tuon perinteen erikoislaatuisuus haluttiin osoittaa tekemällä haastatteluja myös valituissa lähikylissä. Aikansa edistyksellisintä kenttätyövälineistöä edustavat (mukana kannettaviksi riittävän kevyet) kelanauhurit mahdollistivat kaikkien haastattelujen tallentamisen kokonaisuudessaan kylissä, joihin ei tuolloin vielä ollut tieyhteyttä. Projektin tuloksena syntyi massiivinen tutkimusaineisto, jota myöhemmin vielä laajennettiin liittämällä siihen kenttätöiden tuloksia eri puolilta Saamenmaata. Kun arkistossa aloitettiin vanhojen aineistojen digitointi 1990-luvun lopulla, oli arvokkaimpana ja uhanalaisimpana pidetty saamelaiskokoelma itsestään selvä valinta digitointihankkeen pilottiprojektiksi. (Mahlamäki \& Enges 2001; Enges 2012, 35-56.)

Talvadas-projektin alkuvaiheissa 1960- ja 1970-luvuilla kenttätyöteknologia ja -metodologia ottivat isoja edistysaskeleita, mutta tutkittavien asemaan ja oikeuksiin ei tuolloin juuri kiinnitetty huomiota. Tutkimuseettiset, esimerkiksi tutkimuksen valtasuhteisiin ja tuotetun aineiston omistajuuteen liittyvät kysymykset eivät vielä olleet ajankohtaisia, ja ajatus siitä, että tutkimuksen kohteena olevilla ihmisillä olisi oikeus saada jotakin vastineeksi osallistumisestaan, oli vasta tulollaan. Aineiston säilyttämiseen ja käyttöön liittyviä lupia ei kysytty, eivätkä tutkittavat osanneet sellaisia vaatia. Vasta projektin vuosina 2001-2004 toteutetussa seurantavaiheessa pyydettiin systemaattisesti haastateltavilta lupa äänittämiseen sekä äänitteen arkistointiin ja jatkokäyttöön tutkimuksessa ja opetuksessa.

\section{Tutkijoiden ja paikallisten puheenvuoroja}

Dálvadasa šurra, šárra ja hurra -seminaari järjestettiin kaksikielisenä Saamelaisarkiston ja Turun yliopiston historian, kulttuurin ja taiteiden tutkimuksen arkiston yhteistyönä. Sen kantavana teemana oli aineiston palautus ja konkreettisena tavoitteena tiedon jakaminen paikalliselle väestölle siitä, mistä projektissa oli kysymys ja miten omien sukulaisten kuvista ja haastatteluäänitteistä voi saada arkistosta kopioita.

Seminaarin ensimmäinen puhuja oli Nuvvuksen kylässä syntynyt ja siellä koko ikänsä elänyt, nyt 81-vuotias Piera Guttorm. Hän kertoi Tenojokilaakson entisestä elämästä keskittyen lähinnä elinkeinoihin. Hän kuvaili perinteistä kalastusta, metsästystä, karjataloutta, 
poronhoitoa ja marjastusta sekä erilaisia miesten ja naisten käsitöitä, jotka yhdessä muodostivat tenolaisen talousvuoden ja elämänmuodon perustan. Tenojoessa veneväylää noudatteleva Suomen ja Norjan välinen raja oli käytännössä huomaamaton ja on sitä edelleen: rajaelämä jatkuu entisenlaisena, eivätkä kieli- ja valtionrajat erota naapuruksia, jotka usein ovat myös sukulaisia keskenään. Piera Guttorm muisteli myös isäänsä Jouni Guttormia, joka kuului Talvadas-projektin 1960-luvun haastateltaviin, ja tämän tapaa välittää paikallista historiallista tietoa perheen nuoremmalle polvelle "iltaseminaarien" muodossa. Näin tuli kuvatuksi yksi perinteen välittymisen kanava, joista tutkijat alun alkaen olivat erityisen kiinnostuneita.

Piera Guttormin tutkimuskenttää taustoittavasta esityksestä oli luontevaa siirtyä itse projektiin. Itseoikeutetusti ensimmäisen tutkijapuheenvuoron piti professori emeritus Juha Pentikäinen, koko tutkimushankkeen primus motor. Pentikäinen aloitti vapaamuotoisen esityksensä näyttämällä filmin, joka oli kuvattu jo ennen projektin alkua vuonna 1966. Siinä projektin nuoret tutkijat - Pentikäisen ohella Lauri Honko ja Matti Morottaja - ottavat ensituntumaa tulevaan tutkimuskenttäänsä. Muutenkaan Juha Pentikäisen esitys ei ollut varsinaisesti tieteellinen esitelmä, vaan pikemmin itsereflektiivinen katsaus projektin historiaan ja sen merkitykseen tutkijan omassa elämässä. Hän korosti projektiaineiston ylisukupolvista merkitystä ja arvioi, että nyt olisi aika ottaa arkistoitu materiaali aktiivisesti alueen saamelaisväestön omaan käyttöön esimerkiksi matkailuelinkeinoa palvelevana resurssina. Pentikäinen näki tulevaisuuden valoisana: kenttätutkimus, arkistojen entistä aktiivisempi rooli tiedon tallentamisessa ja jakamisessa sekä yhteistyö tutkijoiden ja paikallisen väestön välillä tulevat jatkumaan ja syvenemään.

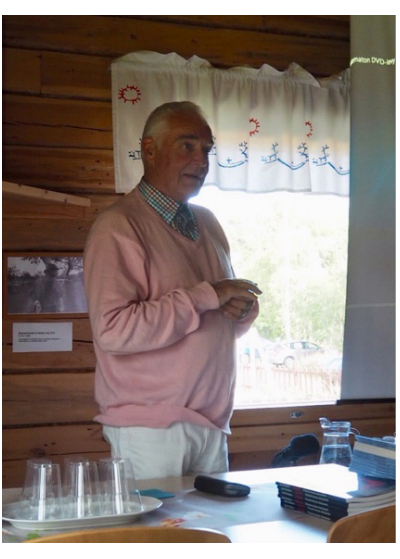

Juha Pentikäinen luennoimassa seminaarissa.

Pasi Enges käsitteli esityksessään Talvadas-haastatteluissa keskeisessä asemassa olleita yliluonnollisia aihepiirejä. Otsikolla "Taasko kysellään staaloista" hän pyrki perustelemaan, miten erilaisiin uskomusolentoihin liittyvät ja läpi projektin toistuvat haastattelukysymykset olivat tutkimustavoitteiden kannalta relevantteja, vaikka saattoivatkin ainakin osasta haastateltavia tuntua turhanpäiväisiltä. Niiden avulla oli mahdollista seurata perinneviestien välittymiskanavia kylässä ja tehdä havaintoja eri yksilöiden suhtautumisesta aihepiireihin. Enges myös korosti laajan, 1960-luvulta 2000-luvulle asti kartutetun aineiston ainutlaatuisuutta: se ulottuu useaan sukupolveen ja valaisee ainutlaatuisella tavalla uskomusperinteen yksilö- ja tilannekohtaista variaatiota.

Oulun yliopiston Giellagas-instituuttia edustava Taarna Valtonen kartoitti puheenvuorossaan Talvadas-aineiston käyttömahdollisuuksia eri tieteenaloilla. Hän totesi projektiaineiston ja erityisesti sen saamenkielisten haastattelujen olevan merkittävä paikallis- ja mikrohistorian lähde, jonka tarjoama tieto ulottuu 1700-luvulle saakka. Haastattelut sisältävät myös näytteitä vanhemmasta kielestä ja sen käyttötavoista sekä perinteistä terminologiaa. Arkistoaines voi joko sellaisenaan tai uusilla kenttätutkimuksilla täydennettynä palvella paikannimitutkimusta, kielen ja sen muutosten tutkimusta sekä arkeologisia, kansatieteellisiä ja historiantutkimuksen näkökulmia. Valtonen itse on tutkinut paikannimiä ja jäljittänyt nimistön erilaisia muotoja, kartoista puuttuvia nimityksiä ja paikannimien käyttöä erilaisissa puhetilanteissa. Paikannimet kertovat nimeämisen ja kulttuurin suhteesta, ja niihin saattaa liittyä niin joikuja, kertomusperinnettä kuin elinkeinohistoriallista tietoa. 
Seminaarin toisen sisäryhmäläisen näkökulmaa edustavan puheenvuoron piti Mikkel Rasmus Logje, Talvadas-projektin keskeisiin haastateltaviin kuuluneen Rasmus-suvun jälkeläinen. Hän oli lapsena kuullut Dálvadaksessa käyneistä tutkijoista, mutta ei ollut tiennyt tutkimusprojektista mitään ennen kuin se tuli vastaan omien opintojen yhteydessä vuonna 2016. Se herätti kiinnostuksen oman perheen ja suvun kertomusperinteeseen ja mestarikertojiin. Esityksessään Mikkel Rasmus Logje kertoi tarinoista ja sanonnoista ja kuvaili tilanteita, joissa niitä esitettiin. Tarinoita
kerrottiin erityisesti keittiön pöydän ääressä. Àhkkun (mummon) laittaessa ruokaa áddja (ukki) kertoi monenlaisista olennoista, joihin lapsena oli helppo uskoa. Vielä nykyäänkin, sukulaisten kokoontuessa Dálvadakseen, istutaan Tenon rannalla tarinoimassa ja muistelemassa vanhoja tapahtumia. Erityisen suosittuja ovat kummitustarinat. Kertomusten välityksellä Mikkel on tutustunut itseään ennen eläneisiin henkilöihin ja kokee ikään kuin tuntevansa heidät, niin eläviksi kertomukset ovat heidät tehneet.

Arkistoaineistolla on joskus keskeinen rooli perinteen elvyttämisessä. Arkeologi ja kulttuuriperinnön tutkija Eeva-Kristiina Harlin keskittyi esityksessään lähes sata vuotta Kansallismuseon kokoelmiin kuuluneeseen naisen sarvilakkiin. Diaaritiedon mukaan lakki on ostettu Dálvadaksesta vuonna 1902 ja tarkempi tutkimus paljastaa, että lakki on kuulunut kylästä lähtöisin olevan kuvataiteilija Outi Pieskin esiäidille. Sama lakki on eri kuvissa ja asetelmissa asetettu erilaisiin asiayhteyksiin, joissa se on lähinnä edustanut suomalaisten stereotyyppistä kuvaa saamelaisista. Harlin ja Pieski ovat yhdessä tehneet museo- ja arkistotutkimusta Suomessa ja Euroopassa, ja onnistuneet saamaan lakista mallin ja kaavat, joiden mukaan se on voitu rekonstruoida. Sarvilakki ei ole ollut mikä tahansa "lapinvaimon päähine", vaan aina jonkun nimenomaisen naisen itselleen omin käsin tekemä. Palautuksen

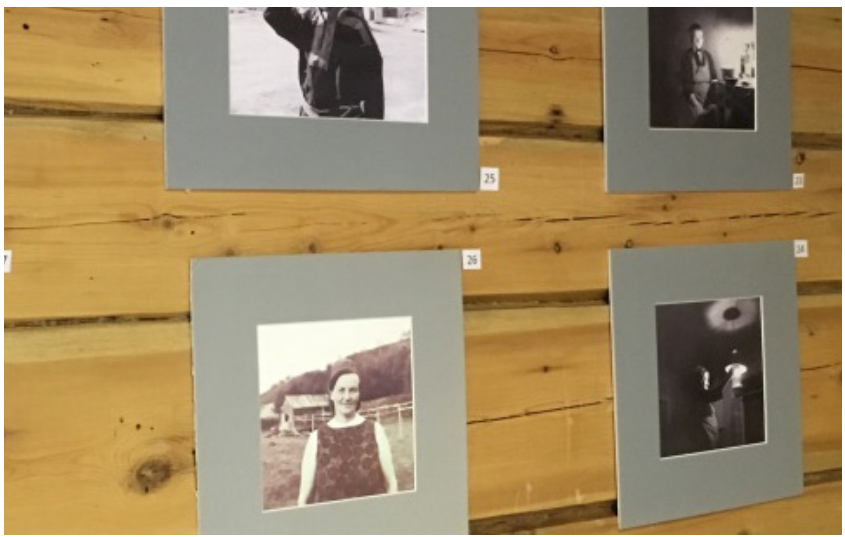

Kylätalon seiniä kiersi Talvadas-projektin aineistosta koottu valokuvanäyttely.

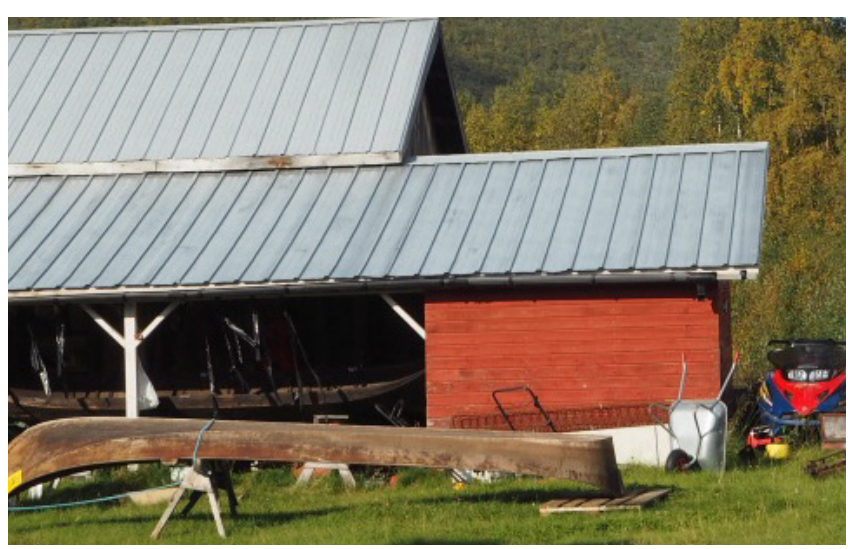

Seminaarin yhteydessä tehtiin myös retki Dálvadaksen kylään.

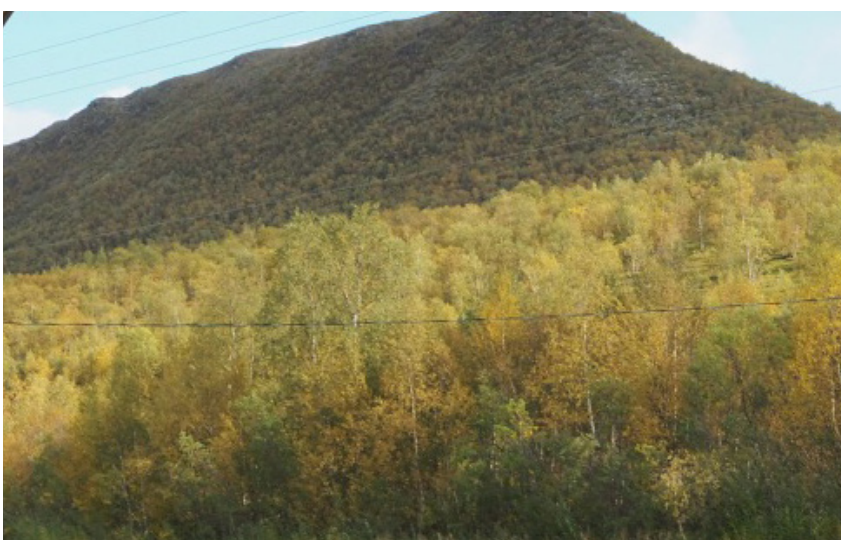

Nuvvuksen Ailigaksen tunturi, jonka kyljessä näkyvät Staalon ladut ovat synnyttäneet monia kertomuksia.

Kuvat: Tiina Mahlamäki 2018 nimissä Harlin ja Pieski ovat kiertäneet eri puolilla kertomassa lakista ja pitäneet työpajoja, joissa naiset ovat voineet tehdä itselleen oman sarvilakin. Välillä unohduksissa olleesta, nyt uudelleen käyttöön otetusta päähineestä voi muodostua saamelaisen vastarinnan ja vahvan saamelaisen naiseuden näkyvä symboli. (Ks. myös Lakkala, West ja Torikka 2017.) 
Tiina Mahlamäki toi tervehdyksen Turun yliopiston historian, kulttuurin ja taiteiden tutkimuksen arkistosta sekä erityisesti siitä, miten eri vuosikymmeninä Talvadas-kokoelman aineistosta on huolehdittu. Aineiston digitointiprojekti aloitettiin 2000-luvulle tultaessa juuri palautuksen hengessä: sähköisessä muodossa aineistoa on voitu antaa käyttöön vaikkapa Saamelaisarkistossa ja Oulun yliopiston Giellagas-instituutissa. Nyt aineisto on siirretty uuteen, entistä paremmin nykyajan vaatimuksiin soveltuvaan Mediabank-tietokantaan ja aikanaan aineistosta löytyy tietoa myös kirjastojen, museoiden ja arkistojen yhteisestä Finna-tietokannasta.

Vaikka arkistoitu ja digitoitu aineisto on tarkoitettu nimenomaan tutkimus- ja opetuskäyttöön, on perheenjäsenten, jälkeläisten ja sukulaisten mahdollisuus saada nähtäväkseen esivanhempiensa ja sukulaistensa kuvia ja kuultavakseen heidän haastattelujaan. Suomalaisen ja eurooppalaisen tietosuojaa koskevan lainsäädännön kehyksissä aineistoa suojellaan asiattomalta käytöltä, minkä vuoksi aineistoista kiinnostuneiden onkin ensin täytettävä käyttöehtositoumuslomakkeet. Informanttien suojelu on keskeinen tutkimuseettinen tehtävä arkistossakin.

\section{Lahjat ja vastalahjat}

Yksi tapa lähestyä kulttuurista repatriaatiota on ymmärtää se maussilaisittain lahjanvaihdoksi (Skrydstrup 2009, erit. 63). Tutkijan pyynnöstä tapahtuva, aikaa ja toisinaan voimiakin vaativa kenttätutkimukseen osallistuminen on lahja, jonka arvoa ei välttämättä aina muisteta. Tutkijoiden vuosikymmenien mittaan yhteistyökumppaneilleen antamat vastalahjat ovat olleet varsin pieniä: osallistumista arkisiin askareisiin, tuliaisia ja satunnaista yhteydenpitoa, joskus myös tutkimustulosten saattamista tutkittavien luettavaksi. Vaatimattomaksi vastalahja jäi tälläkin kertaa, mutta Dálvadasa šurra, šárra ja hurra -seminaaria voi pitää lupaavana alkuna yhteistyölle, jossa arkistoaineistot ovat helpommin niiden tuottamiseen osallistuneiden ihmisten ja heidän jälkeläistensä saavutettavissa, ja jossa vastavuoroisuuden periaate todella toteutuu. Seminaari on jo tuottanut tulosta: historian, kulttuurin ja taiteiden tutkimuksen arkisto on ottanut vastaan useampia sekä tutkijoiden että paikallisten ihmisten yhteydenottoja ja aineistopyyntöjä.

\section{Lähteet}

Aromaa, Jonni. 2017. "Tämä nukke palaa Saamenmaalle - Kansallismuseo siirtää saamelaiskokoelmansa sinne minne se kuuluu." https://yle.fi/uutiset/3-9544608.

Enges, Pasi.2012."Minämelkeinuskon": Yliluonnollinenjasenkohtaaminentenonsaamelaisessa uskomusperinteessä. Turku: Turun yliopisto..

Harlin, Eeva-Kristiina. 2008. Recalling Ancestral Voices - Repatriation of Sámi Cultural Heritage. Interreg IIIA -projektin loppuraportti. http://www.samimuseum.fi/heritage/suomi/ Loppuraportti/loppuraportti.pdf.

Lakkala, Aletta, Helga West ja XiaTorikka. 2017. "Saamelaisnaisten muinainen, mahdollisesti syntisenä kielletty sarvilakki halutaan jälleen käyttöön." https://yle.fi/uutiset/3-9743691. 
Mahlamäki, Tiina ja Pasi Enges. 2001. "From the Field to the Net: Analysing, cataloguing and digitising the material of the Saami Folklore Project." Teoksessa Input \& Output: The Process of Fieldwork, Archiving and Research in Folklore. NNF Publications 10, toimittaneet Ulrika Wolf-Knuts, Anders Salomonsson, Ann Helene Bolstad Skjelbred ja Ríonach uí Ógáin, 115-130. Turku: Nordic Network of Folklore.

Skrydstrup, Martin. 2009. "Theorizing Repatriation." Ethnologia Europaea. 39(2): 54-66.

FT Pasi Enges on folkloristiikan yliopistonlehtori ja FT, dosentti Tiina Mahlamäki uskontotieteen yliopistonlehtori Turun yliopistossa. 